\title{
HOW DID THE 2003 PRESCRIPTION DRUG RE-IMPORTATION BILL PASS THE HOUSE?
}

\author{
OMer GokceKus*, MiKe AdAms, Henry Grabowski, \\ AND EDWARD TOWER
}

\begin{abstract}
We examine the major interest groups in the debate over allowing the re-importation of prescription drugs by utilizing a logit model and instrumental variables. Consistent with political support approach, the evidence suggests that Representatives are maximizing their electoral prospects: contributions from pharmaceutical manufacturers shrink the probability of voting for the bill; and Representatives are sensitive to their constituencies - employees of pharmaceutical manufacturing and senior citizens. Representatives' gender and ideology regarding free trade and subsidies are also determining factors. However, the decision was, by and large, a partisan one: party affiliation was the most important factor in passing the bill.
\end{abstract}

\section{INTRODUCTION}

ON JULY 25, 2003, the US House of Representatives passed the Pharmaceutical Access Act of 2003 (H.R. 2427), by a margin of 243 to 186, paving the way for re-importation of drugs into the United States. Given the enormous money at stake in this bill - estimated at $\$ 1.8$ trillion by the Congressional Budget Office - H.R. 2427 spurred perhaps the fiercest mobilization of political lobbyists in 2003. The bill passed the House of Representatives despite extensive lobbying and a staggering \$29 million spent by large pharmaceutical companies attempting to defeat the bill. ${ }^{1}$ The US pharmaceutical industry trade group (Pharmaceutical Research and Manufacturers of America, PhRMA) alone spent $\$ 8.5$ million on political contributions in the first half of 2003 in a concerted effort to defeat H.R. 2427. Conventional wisdom among Washington observers holds that political contributions from industry players is an essential - if not decisive - factor in legislative decision-making. Given the sheer size of these contributions, the fact that H.R. 2427 was able to muster enough support to pass the House is intriguing. ${ }^{2}$

\footnotetext{
*Corresponding author: Omer Gokcekus, John C. Whitehead School of Diplomacy and International Relations, Seton Hall University, S. Orange, NJ 07079, USA. E-mail: gokcekom@ shu.edu

${ }^{1}$ Among others, Baldwin and Magee (2000), Fisher et al. (2004), Frendreis and Waterman (1985), Kau and Rubin (1982), Langbein and Lotwis (1990), Saltzman (1987), and Schroedel (1986) provide supporting evidence that indeed contributions significantly affect votes.

${ }^{2}$ Current status of the bill: On October 22, 2003, Mr. Dorgan introduced S. 1781 - the Senate version of the "Pharmaceutical Market Access Act of 2003," which was referred to the
} 
Why, then, did a massive lobbying campaign by one of the most powerful US interest groups, large pharmaceutical manufacturers, fail to bring about the desired legislative outcome? This question provides the impetus for our study of the factors affecting the decision-making of US legislators on this issue. Accordingly, we identify the factors that influence legislative decisionmaking; and second, we estimate the relative weighting of these factors. The purpose of this project was to analyze what role campaign contributions and demographics, such as the percentage of people over the age of 65 in each Representative's congressional district, had on the voting behavior of the Representatives.

\section{THE ISSUE}

The rising cost of prescription drugs in America has become a big concern both for politicians and the public. Dan Burton, the Chairman of the House Government Reform Subcommittee on Human Rights and Wellness, noted that American consumers pay a higher average price for prescription drugs than consumers in any other country. He goes on to explain that drug costs have been increasing by more than 17 percent annually from 1998 to 2001 . This is approximately five times the rate of inflation and has created a situation where more than one in five American adults are unable to afford their prescription drugs (Burton, 2003).

The Pharmaceutical Market Access Act, championed by Representatives Gil Gutknecht and Rahm Emanuel, authorizes pharmacists, wholesalers, and other qualified individuals to import pharmaceuticals from 26 countries back to the United States for distribution to consumers. The goal of this is to "give all Americans immediate relief from the outrageously high cost of pharmaceuticals" and to "reverse the perverse economics of the American pharmaceutical markets" (U.S. House of Representatives, 2003).

Supporters of the bill claim that it would accomplish this goal by granting American consumers access to drugs in foreign countries where they are much cheaper. Gutknecht (2003) claims that, on average, Americans pay 30300 percent more than consumers in other industrialized countries for the same prescription drugs. According to Brink (2003), Americans pay more because so many of them pay for their prescriptions individually, while the centralized healthcare systems of other countries, such as Canada, France, and Germany, use the bargaining power of an entire population to negotiate prices.

Leading up to vote on the bill in Congress, there was a heated debate centered around two major issues. The first of these is whether or not it is 
safe to import prescription drugs from other countries where they are outside the jurisdiction of the Food and Drug Administration (FDA). Mark McClellan, the Commissioner of the FDA, stated, "We still can't assure safety and quality because the products are outside of our authority. The situation remains 'Buyer Beware' and that's not a good way to insure public health" (PhRMA, 2003a). One fear is that this bill has included countries that are known to have problems with counterfeit drugs. Rep. Jim Gibbons notes reports from South Africa that up to 20 percent of the medicines sold are fakes or stolen (Gibbons, 2003). Another concern is that improper shipping and storage of drugs may cause them to lose their potency (Biotechnology Industry Organization, 2003). Those in favor of the bill argue that steps can be taken to insure that there is no risk in importing American drugs. The bill states that the United States can import only FDAapproved drugs that have been produced at home, and requires that "imported prescription drugs be packaged and shipped using counterfeitresistant technologies approved by the Bureau of Engraving and Printing similar to those used to secure United States currency" (U.S. House of Representatives, 2003). This would help ensure that drugs could be shipped back to the United States only in their original packaging. Rep. Jo Anne Emerson, a strong supporter of the bill, said, "We can uphold the integrity of the product. These are just bogus issues that they've created to make people nervous about these drugs" (Moyers, 2003).

The second major criticism of the Pharmaceutical Market Access Act is that it would hurt pharmaceutical research and development. According to Krauss (2003) the bargaining power of foreign countries allows them to set drug prices which are just above the marginal cost of production. These prices are much lower than the average cost of production, which includes all the research and development costs that are required to develop new prescription drugs. Since the majority of pharmaceutical research is done in the United States, foreign countries free-ride off American consumers, who end up covering more than their fair share of the cost of research and development. Krauss (2003) fears that if Americans stop paying higher prices for drugs, the incentive to invest in research and development of new drugs will decrease, eventually leading to a slowdown in the pace of medical innovation. On the other hand, defenders of the bill argue that pharmaceutical companies are more than making up for this problem of free-riding, and that lower prices would not hurt research and development. Rep. Emerson says, "This bill is fair to everybody. If a pharmaceutical company that has a 27 percent profit margin only sees 20 percent after this law is passed, they'll still be doing pretty good" (Moyers, 2003). The pharmaceutical industry argues that high returns from successful products are needed to encourage investment because of the risks associated with spending huge amounts of money on products that may never make it to the market (Comanor, 1986). Reinhardt (2001, p. 144) estimated that drug profits constitute only 1 percent 
of total national health spending; thus, even if all of the profits of the drug industry were confiscated, it would not make much of a dent in national health spending - about $\$ 50$ per person. ${ }^{3}$

\section{FOUR SPECIAL INTEREST GROUPS}

We identify four major groups with an interest in the battle of H.R. 2427: (i) pharmaceutical manufacturers; (ii) senior citizens; (iii) HMOs; and (iv) border districts. Currently, the US pharmaceutical industry is able to charge Americans enough to cover its research and development costs and still profit from foreign countries who pay prices that are just above marginal costs. If the bill were to become law, pharmaceutical manufacturers would either have to let US prices fall in line with the rest of the world, or limit exports of their products. Either way, their profits would be hurt. Clearly, there was a lot at stake for the US pharmaceutical industry, and as such, its lobbying efforts were aimed at defeating the bill. These efforts were led by the PhRMA, which represents many of the largest pharmaceutical manufacturers, e.g. Eli Lilly and Company, GlaxoSmithKline, Merck, Novartis, and Pfizer. Their strong opposition to H.R. 2427 can be seen from a statement posted on their website: "the Gutknecht importation bill is dangerous legislation that jeopardizes the safety of our nation's medicine supply and imports foreign governments' price controls" (PhRMA, 2003b).

Thus, the pharmaceutical industry has the incentive to work to maintain this position. As Table 1 shows, they have a strong history of working to influence government policies and are consistently among the biggest contributors to the re-election campaigns of legislators. Beyond possessing the financial resources necessary to influence policy, pharmaceutical companies have additional power as employers. Because they employ large numbers of people, the number of people employed in the pharmaceutical industry within a Representative's district is another important indicator of the influence that pharmaceutical companies may exert on that Representative. ${ }^{4}$

The second group with an interest in this battle is senior citizens. On average, people over the age of 65 fill five times as many prescriptions as any other age group of Americans (Brink, 2003): they have a strong incentive to follow this drug legislation and to lobby for passage of the bill. Therefore, seniors are informed voters, and since this group makes up approximately 20 percent of the voting population, they have a powerful voice (Brink, 2003). Moreover, senior citizens are known to be active voters, whereas other demographics often fail to show up on election day. The AARP, the largest and most effective group lobbying for seniors, clearly states on its

\footnotetext{
${ }^{3}$ For two interesting analyses of drug re-importation and its effects on prices and profitability of domestic companies, see Pecorino (2002) and Ganslandt and Maskus (2004).

${ }^{4}$ For this data, we use employment statistics in four-digit pharmaceutical manufacturing industry, i.e. ISIC 3254. Source: US Bureau Labor Statistics, www.bls.gov.
} 
Table 1 Pharmaceutical Manufacturing Long-Term Contribution Trend: 1990-2002

\begin{tabular}{|c|c|c|c|c|c|c|}
\hline \multirow[b]{2}{*}{$\begin{array}{l}\text { Election } \\
\text { cycle }\end{array}$} & \multirow[b]{2}{*}{$\begin{array}{c}\text { Total } \\
\text { contributions }\end{array}$} & \multicolumn{3}{|c|}{ Type of total contributions } & \multicolumn{2}{|c|}{ Recipients of contributions } \\
\hline & & $\begin{array}{c}\text { From } \\
\text { individuals } \\
(\%)\end{array}$ & $\begin{array}{c}\text { From } \\
\text { Political } \\
\text { Action } \\
\text { Committees } \\
\text { (PACs) }(\%)\end{array}$ & $\begin{array}{l}\text { Soft } \\
\text { money } \\
(\%)\end{array}$ & $\begin{array}{c}\text { Donations to } \\
\text { Democrats } \\
(\%)\end{array}$ & $\begin{array}{c}\text { Donations to } \\
\text { Republicans } \\
(\%)\end{array}$ \\
\hline 2002 & $\$ 21,749,155$ & 7 & 25 & 68 & 20 & 80 \\
\hline 2000 & $\$ 19,638,447$ & 16 & 24 & 59 & 23 & 77 \\
\hline 1998 & $\$ 9,031,146$ & 13 & 35 & 51 & 31 & 69 \\
\hline 1996 & $\$ 9,265,843$ & 15 & 31 & 54 & 29 & 71 \\
\hline 1994 & $\$ 5,378,722$ & 17 & 52 & 32 & 40 & 61 \\
\hline 1992 & $\$ 4,905,427$ & 24 & 49 & 27 & 49 & 52 \\
\hline 1990 & $\$ 2,338,670$ & 19 & 81 & $\mathrm{~N} / \mathrm{A}$ & 44 & 57 \\
\hline
\end{tabular}

Source: www.opensecrets.org, web page of the Center for Responsive Politics.

web page that it does not contribute in an "organized" way to the legislators" re-election campaigns. However, from Federal Election Committee's records, it is possible to identify whether the money received by a Representative for a re-election campaign is from a retired person or not. Moreover, for each congressional district, it is possible to identify the percent of the population that was above age $65 .{ }^{5}$ Representatives know that voting against this bill may cause them to lose the support of seniors. This variable captures the influence that a group of voters - who support the bill - have on their Representative's vote.

The third group with an interest in H.R. 2427 is HMOs. HMOs stand to gain much by the implementation of this bill. If US drug prices were to decrease, it would cost HMOs less to supply their clients with the prescriptions; this decreased cost would improve the profits of HMOs.

The fourth group with a vested interest in H.R. 2427 is border states. Seniors have organized bus trips in states close to the borders with Canada and Mexico to fill their prescriptions more cheaply. Although technically illegal, customs officials have been allowing these border-crossers to fill their personal prescriptions for up to a three-month supply (Brink, 2003; Flaherty and Gaul, 2003). Chellie Pingree, a former Senator from Maine, said, "The last bus trip I was on 6 months ago had 25 seniors. Those 25 people saved $\$ 19,000$ on their supplies of drugs" (Brink, 2003). We predict that people living in a district with easy access to Canada or Mexico would be more in favor of passing a bill allowing drug importation. We make this prediction not because this population would benefit most under the new legislation pharmacies all over the country could import drugs directly and thus everyone should benefit equally. Rather, it is because they are most aware of 
the price inequalities and are the most likely to have either already crossed borders to save money, or have heard stories of others who have done so. In effect, this creates another group of informed voters who support the issue.

\section{ANALYSIS}

Again, the fundamental question is: what factors affected the legislators' decision? To answer this question empirically, we model the probability that a Representative votes yes on the bill, as a function of contributions received from pharmaceutical manufacturers, HMOs, and retired people, the number of people employed by pharmaceutical manufacturers, the number of senior citizens in a Representatives' district, and whether the Representatives' district has a border with Canada or Mexico. ${ }^{6}$

\subsection{The Model}

In this study, we adopt the perspective of the political-support approach (Grossman and Helpman, 1994, 1996; Hillman, 1982). According to this approach, incumbent politicians make policy choices with the knowledge that their decision may affect their chances for re-election. Organized interest groups are able to offer political contributions, which politicians value for their potential use in the coming election. It is this ability to contribute that gives special interest groups their favored position in the eyes of legislators. The legislators attempt to set policies and vote in ways designed to maximize their own welfare, which is a weighted average of the well-being of their constituency and total contributions they will receive.

Accordingly, in this section we estimate nine different models, which cover a range of specifications found in the literature. (As we explain later, we see these models as variants of three main model categories, namely: $A$ Naïve "Big Money and Partisanship" Model; An Incomplete Political Support Model; and A Political Support Model.) In these models, the dependent variable is the roll-call vote by each Representative on this bill (VOTE), where votes were counted as 1 for aye and 0 for nay, with a nay vote registering a preference against re-importation of drugs. Due to the limits on the values that the dependent variable may take, logit analysis was used rather than linear regression. The logit analysis makes the probability of a yes vote a function of a vector of constants $(\beta)$, times a vector of values for the independent variables $(x){ }^{7}$ We use the following logit probability model:

$$
\operatorname{Prob}(\operatorname{VOTE}=1)=\frac{e^{\beta x}}{1+e^{\beta x}} .
$$

\footnotetext{
${ }^{6}$ As we explain in the following section, we use instrumental variables to address the endogeneity issue.

${ }^{7}$ For details of logit models, see Greene (2003). For recent applications of this model in legislative voting, for example, see Baldwin and Magee (2000), Fennemore and Nelson (2001), Gokcekus et al. (2004), and Longley (2003).
} 


\subsection{Independent Variables}

The independent variables are the following: PHARMA-CONTRIBUTE, campaign contributions received from pharmaceutical manufacturers during the 2002 election cycle until June 9, 2003, in \$1,000; PHARMAEMPLOYMENT, number of people employed in pharmaceutical manufacturing sector, measured in 1,000s; RETIRED-CONTRIBUTE, campaign contributions received from retired people during the 2002 election cycle and until June 9, 2003, in \$1,000; AGE65+, percentage of the congressional district's population who are 65 years or older; BORDER, congressional district has a border with Canada or Mexico (if $\mathrm{Yes}=1$, if $\mathrm{No}=0$ ) ${ }^{8}$ HMO-CONTRIBUTE, campaign contributions received from HMOs during the 2002 election cycle and until June 9, 2003, in \$1,000; PARTY, political party affiliation of a Representative (1 if Republican, 0 otherwise); FREE TRADER, Representative's ideology regarding trade and markets ( 1 if he/she opposes trade barriers and subsidies, 0 otherwise); INTERNATIONALIST, Representative's ideology regarding trade and markets ( 1 if opposes trade barriers but supports subsidies, 0 otherwise); and FEMALE: gender of a Representative ( 1 if female, 0 if male).

As this list shows, in an attempt to control for political party affiliation, we include a dummy variable, PARTY, that takes the value 1 for Republicans and 0 otherwise. The ideological views of each party suggest that Democrats are more in favor of the bill than Republicans are. Therefore it is predicted that being a Democrat would increase the probability of an aye vote. There is a wide spectrum in each party regarding the ideology of its members because of the two-party system in the US; therefore, PARTY is a very rough way of capturing the ideology of Representatives. Moreover, we also recognize the possibility that this proxy may conflate ideology and party line. Obviously, within each party, there are differences among Representatives' positions regarding international trade among other issues. Yet, the party may decide, as a party, to have a particular position on the issue. Accordingly, to separate a party's position from individual Representatives' positions, we also include two dummy variables, i.e. FREE TRADER and INTERNATIONALIST. A recently published Cato Institute report, Griswold (2005), categories Representatives in the 108th Congress based on their position on trade barriers and subsidies. ${ }^{9}$ FREE TRADERs are characterized as those who oppose both barriers and subsidies, and INTERNATIONALISTs oppose barriers but support subsidies. Thus, we compare these two groups with those who support barriers or have no clear position

\footnotetext{
${ }^{8}$ List of Congressional Districts with Canadian Borders: Alaska 1; Idaho 1; Illinois 1-10; Maine 2; Michigan 1; Minnesota 7, 8; New Hampshire 2; New York 23, 25, 28, 32; North Dakota 1; Ohio 9, 10, 11, 14; Pennsylvania 3, 5, 10; Vermont 1; Washington 1, 2, 5, 6, 7, 9; Wisconsin 7. List of Congressional Districts with Mexican Borders: Arizona 7, 8; California 49-53; New Mexico 2; Texas 15, 16, 23, 27, and 28.
}

${ }^{9}$ For details, see Griswold (2005, pp. 2-5). 
on them. To control for gender, we include a dummy variable, FEMALE, that takes the value 1 for Representatives who are female and 0 otherwise. ${ }^{10}$

\subsection{Instrumental Variables (IV)}

As is widely acknowledged in the empirical voting literature, there is a potential issue of statistical endogeneity of contributions (for details, see Ansolabehere et al., 2003, and Chappell, 1982). There are two different approaches to address this issue: either estimate contributions and votes simultaneously or use the IV approach. We adopt the second approach in this study. In doing so, we identify two sets of variables that may enable some Representatives to receive contributions without directly affecting their vote for the bill. Accordingly, in the first step, we run regressions using contributions as the dependent variable and the following collection of IV as the independent variables. In the second step, we run regressions where the roll call vote is the dependent variable and the predicted values of contributions from the first step and other relevant variables are independent variables.

In this study, we utilize two sets of IV. First, we choose variables to capture the "degree of electoral competition." To do this, we introduce two new variables as proxies: (i) Money spent per vote in the most recent election and (ii) cash on hand at the end of the previous election cycle. The idea here is that for various reasons it may be expensive to run a campaign in a Representative's district, and therefore there is an extra need for money from special interests to run a successful re-election campaign. Thus, there is a desire and willingness to "sell" services to special interests (such as roll call votes). Second, we choose variables to capture the "power" of a Representative. The rationale here is that special interests give more to powerful Representatives because they are potentially more valuable as legislators. To capture "power," we use four variables: (i) party leader; (ii) committee chair; (iii) member: Ways and Means Committee; and (iv) member: the Energy and Commerce Committee. (For details, see Ansolabehere et al., 2003, p. 115.)

Before we conducted the regression analysis, we took a closer look at two groups of Representatives - those who voted for the bill and those who voted against it. As Table 2 shows, in general, (i) Republicans vote against the bill; (ii) only 64 percent of the YES voters received contributions from pharmaceutical manufacturers, compared with 88 percent of NO voters; (iii) more importantly, NO voters on average received $\$ 14,418$ from pharmaceutical manufacturers compared with $\$ 3,821$ for YES voters; (iv) YES Representatives' districts have significantly higher proportions of senior citizens; and (v) Among Representatives voting NO, 16 percent were from a

\footnotetext{
${ }^{10}$ For gender differences in contributions to public goods, see Brown and Taylor (2000) and Brown-Kruse and Hummels (1993).
} 
Table 2 Descriptive Statistics of the YeS and NO Voting Representatives

\begin{tabular}{|c|c|c|c|c|}
\hline & Vote $=\mathrm{NO}$ & Vote $=$ YES & $\begin{array}{c}t \text {-Statistic } \\
\left(\mathrm{H}_{0}: \text { there is }\right. \\
\text { no difference } \\
\text { between } \\
\text { Representatives } \\
\text { Vote }=\text { NO } \\
\text { and } \\
\text { Vote }=\text { YES })\end{array}$ & $\begin{array}{l}\text { Significance } \\
\text { (two-tailed) }\end{array}$ \\
\hline Republican & $74.6 \%$ & $37.0 \%$ & 8.412 & 0.00 \\
\hline $\begin{array}{l}\text { Received pharma } \\
\text { contributions }\end{array}$ & $87.6 \%$ & $63.8 \%$ & 6.048 & 0.00 \\
\hline $\begin{array}{l}\text { Average pharma } \\
\text { contributions per } \\
\text { Representative }\end{array}$ & $\$ 14,418$ & $\$ 3,821$ & 6.928 & 0.00 \\
\hline $\begin{array}{l}\text { Average HMO } \\
\text { contributions per } \\
\text { Representative }\end{array}$ & $\$ 5,357$ & $\$ 3,646$ & 1.837 & 0.07 \\
\hline Pharma employment & 12,019 & 9,462 & 2.363 & 0.02 \\
\hline Percentage of age $65+$ & $12.0 \%$ & $12.8 \%$ & -2.342 & 0.02 \\
\hline Borders with Mexico & $1.6 \%$ & $4.1 \%$ & -1.578 & 0.12 \\
\hline Borders with Canada & $4.3 \%$ & $11.5 \%$ & -2.832 & 0.00 \\
\hline $\begin{array}{l}\text { Borders with (Mexico or } \\
\text { Canada) }\end{array}$ & $5.9 \%$ & $15.6 \%$ & -3.326 & 0.00 \\
\hline
\end{tabular}

district with a border either with Mexico or Canada. This number was 6 percent for the YES voters.

\subsection{Regression Results}

Table 3 presents the Maximum Likelihood estimation results of nine logit analyses using PHARMA-CONTRIBUTE, PHARMA-EMPLOYMENT, PARTY, FREE TRADER, INTERNATIONALIST, RETIREDCONTRIBUTE, AGE65+, BORDER, HMO-CONTRIBUTE, and FEMALE as our explanatory variables. Ultimately, however, we use only the results for the Political Support Model (with IV's) in our analysis to answer the fundamental question: "what factors affected the legislators' decision;" nevertheless, we decided to include other eight regression results for comparison.

The initial five regression results (columns 1-5) are for the model which naïvely depicts a vote as a function of only big pharmaceutical influence and a Representative's ideology - both party affiliation and individual ideology regarding international trade (A Naïve "Big Money and Partisanship" Model). Using this model without IV's results in (i) insignificant coefficients for PHARMA-EMPLOYMENT and individual ideology 


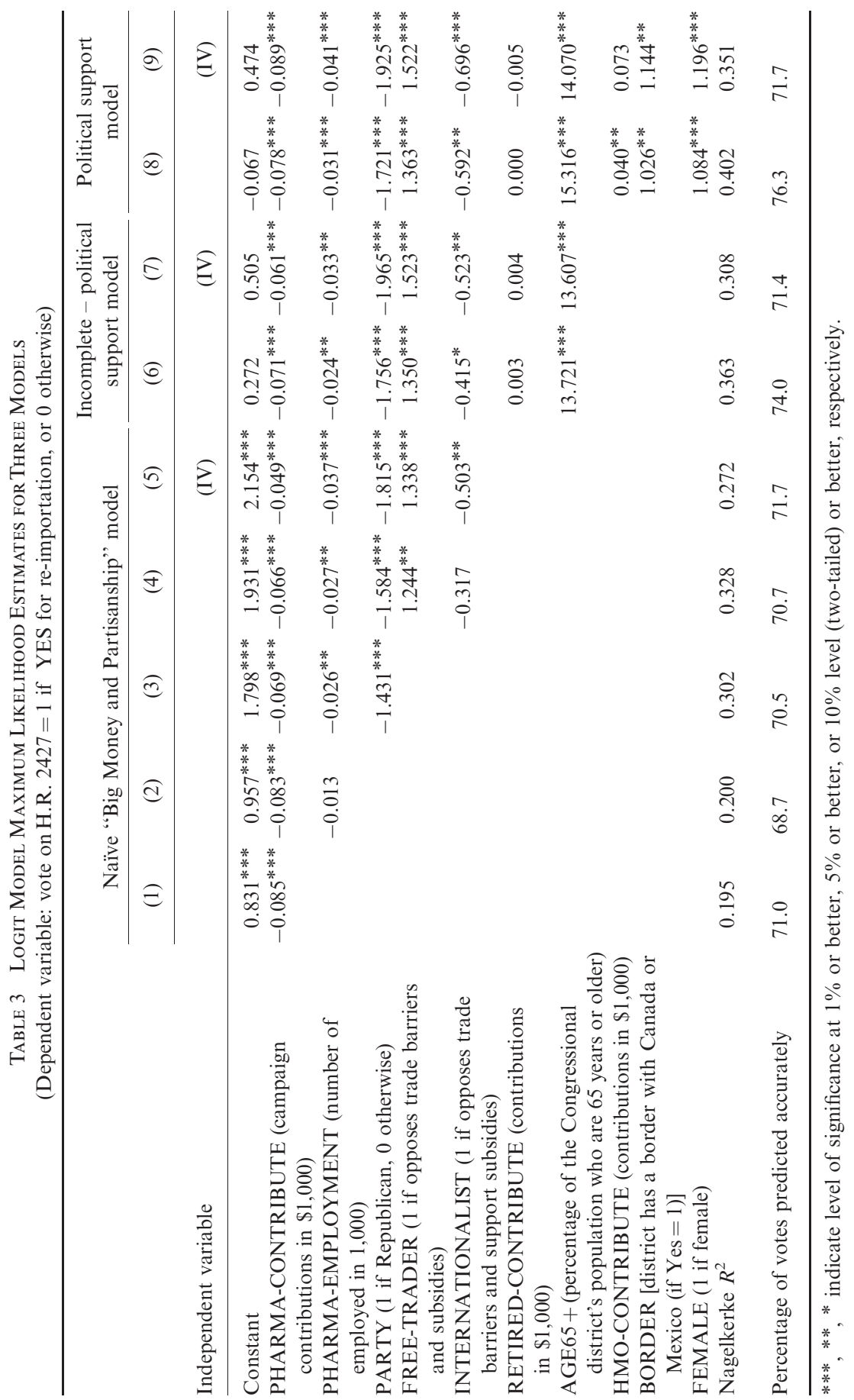


indicators - FREE TRADER and INTERNATIONALIST and (ii) relatively small coefficients for PHARMA-CONTRIBUTE and PARTY. ${ }^{11}$ When IV are introduced, (column 5) the estimated coefficients for all variables are significantly different from 0 at the 1 percent level, except INTERNATIONALIST. Nevertheless, these coefficients are different than those in column 9.

The next two columns (columns 6 and 7) show the regression results for a model which acknowledges that a Representative pays attention to main interest groups - both at the winning and losing end - in case the bill passes, i.e. a Representative takes into account senior citizens' interest in addition to the pharmaceuticals' (An Incomplete Political Support Model). We get statistically significant results for AGE65 + but not for the RETIREDCONTRIBUTE. Furthermore, the magnitude and significance of PHARMA-EMPLOYMENT diminishes.

Finally, columns 8 and 9 show the results for a model that incorporates two other special interest groups: border districts and HMOs. This model also includes the gender of a Representative (A Political Support Model). Because this is the most complete model, Table 4 presents the detailed regression results for this specification.

As Table 4 shows, all coefficients have the predicted signs and are statistically significant at the 1 percent level, except coefficients for HMOCONTRIBUTE and the RETIRED-CONTRIBUTE. Despite our a priori expectations, not getting statistically significant coefficients for these two variables are not necessarily surprising results. First, concerning seniors, those seniors who are financially capable of contributing to a campaign are most likely not in dire need for the Pharmaceutical Market Access Act to pass and may not even support it at all. It is also not clear whether these retired contributors are residing in their recipient Representatives' district. For HMO-CONTRIBUTE, our a priori expectation was a positive effect on the vote because of the cost-cutting implications. However, the size of these potential cost cuts for HMOs may not necessarily be as significant as we thought. For instance, Reinhardt (2001) provides a back-of-an-envelope estimate:

if prescription drugs currently absorb about 15 percent of a health plan's premium (a relatively high estimate), and if spending on prescription drugs per insured in that plan rose by 20 percent (a high estimate as well), then only three percentage points of the total annual increase in that health plan's premium could be attributed to prescription drugs. With premiums again at double-digit levels, that leaves much of these increases to be explained by cost drivers other than prescription drugs [p. 148].

\footnotetext{
${ }^{11}$ We use the "political support model" estimated with IV (column 9) as the benchmark in deriving these comparisons.
} 
Table 4 Logit Model Maximum Likelihood Estimates for "Political Support Model" (Dependent variable: vote on H.R. 2427 = 1 IF YES for re-importation, or 0 otherwise)

\begin{tabular}{lccrc}
\hline Variable & $\begin{array}{c}\text { Coefficient } \\
(\beta)\end{array}$ & $\begin{array}{c}\text { Standard } \\
\text { error }\end{array}$ & $\begin{array}{c}\text { Wald } \\
\text { statistic }\end{array}$ & $\begin{array}{r}\text { Significance } \\
\text { (two-tailed) }\end{array}$ \\
\hline Constant & 0.474 & 0.535 & 0.785 & 0.376 \\
PHARMA-CONTRIBUTE & -0.089 & 0.033 & 7.361 & 0.007 \\
PHARMA-EMPLOYMENT & -0.041 & 0.011 & 13.179 & 0.000 \\
PARTY & -1.925 & 0.252 & 58.376 & 0.000 \\
FREE-TRADER & 1.522 & 0.528 & 8.310 & 0.004 \\
INTERNATIONALIST & -0.696 & 0.250 & 7.712 & 0.005 \\
RETIRED-CONTRIBUTE & -0.005 & 0.009 & 0.269 & 0.604 \\
AGE65+ & 14.070 & 3.770 & 13.925 & 0.000 \\
HMO-CONTRIBUTE & 0.073 & 0.062 & 1.409 & 0.235 \\
BORDER & 1.144 & 0.419 & 7.444 & 0.006 \\
FEMALE & 1.196 & 0.375 & 10.168 & 0.001
\end{tabular}

Frequencies of actual and predicted outcomes

Predicted

\begin{tabular}{ccc}
\hline Vote $=$ NO & Vote $=$ YES & $\begin{array}{c}\text { Percentage } \\
\text { correct }\end{array}$ \\
\hline 128 & 63 & 67.0 \\
60 & 183 & 75.3 \\
& & 71.7 \\
\hline
\end{tabular}

Note: -2 log likelihood $=463.773 ; \chi^{2}=131.634$.

Finally this table demonstrates how well the model predicts the outcomes: 67 percent of the NO votes; 75 percent of the YES votes are accurately predicted by the model - in total 311 of the 434 votes, for a 72 percent accuracy rate.

The story is told in Figure $1 .{ }^{12}$ This figure shows the probability of a YES vote as a function of contributions from pharmaceutical manufacturers to five different types of Representatives: (i) a male Republican who is neither a free trader nor an internationalist, nor from a district sharing borders with Canada or Mexico and with a low presence of seniors, i.e. only 4 percent AGE65+; (ii) a female Republican who is neither a free trader nor an internationalist, nor from a district sharing borders with Canada or Mexico and with a low presence of seniors, i.e. only 4 percent AGE65+; (iii) a male Republican who is neither a free trader nor an internationalist nor from a district sharing borders with Canada or Mexico and with a high presence of seniors, i.e. 16 percent AGE65+; (iv) a female Republican who is neither a free trader nor an internationalist nor from a district sharing borders with

\footnotetext{
${ }^{12}$ We draw Figure 1 because it is not possible to get sense of the marginal effect of each factor on a vote just by looking at the estimated coefficients of a logit model.
} 


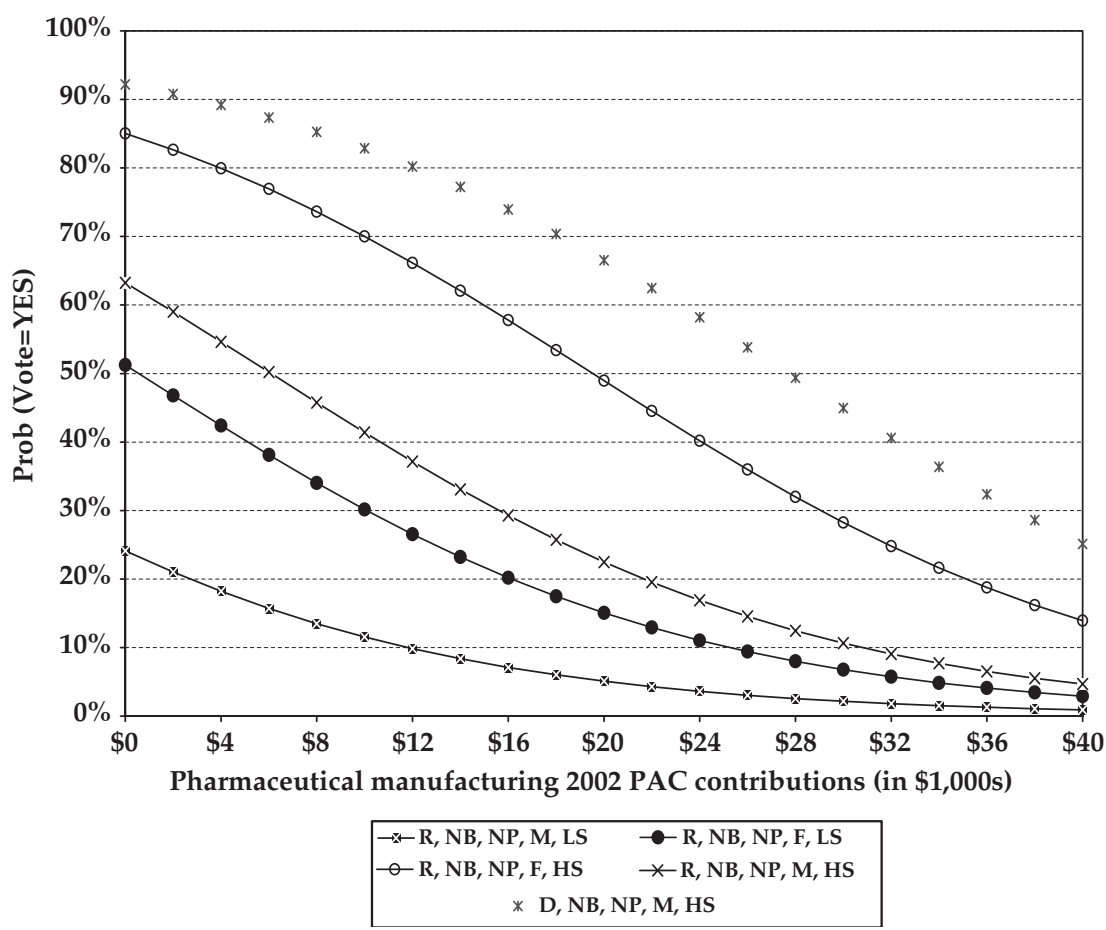

Figure 1. Predicted probability of voting YES on H.R. 2427.

Notes: Where R, Republican; D, Democrat; NB, no border; NP, neither free trader nor internationalist; $\mathrm{M}$, male; F, female; LS, low senior presence $=4$ percent; and HS, high senior presence $=16$ percent.

Canada or Mexico and with a high presence of seniors, i.e. 16 percent AGE65+; and (v) a male Democrat who is neither a free trader nor an internationalist nor from a district sharing borders with Canada or Mexico and with a high presence of seniors, i.e. 16 percent AGE65+. ${ }^{13}$

We see from Figure 1 that for a male Democrat Representative from a district sharing no borders with Canada or Mexico, with a high senior presence, and with no PHARMA-CONTRIBUTE, the probability of a YES vote is 92 percent. For a male Republican from the "same" district with no PHARMA-CONTRIBUTE, the probability of a YES vote is 63 percent. For a female Republican from the "same" district, the probability of a YES with no PHARMA-CONTRIBUTE is 85 percent. The probably of a YES vote can be brought down below 50 percent (which is the logit model's

${ }^{13}$ For each one of these groups, we assume that HMO-CONTRIBUTE $=\$ 4,420$, RETIREDCONTRIBUTE $=\$ 29,854$, and PHARMA-EMPLOYMENT $=\$ 10,521$. In other words, we assign sample average for these variables for each group. Meanwhile, the average AGE $65+=12.4$ percent. 
cut-off line between a YES and a NO vote) if the PHARMA-CONTRIBUTE contributions are raised from $\$ 0$ to $\$ 19,600$. Similarly, for a male Republican whose PHARMA-CONTRIBUTE is 0 , the probability of YES can be brought down from 63 to 49.9 percent by raising the PHARMACONTRIBUTE contribution from $\$ 0$ to $\$ 6,150$. This number is $\$ 27,750$ for a male Democrat in the same district.

Figure 1 also shows that it takes only $\$ 750$ from PHARMA-CONTRIBUTE to reduce the probability of a female Republican (from a district with no Canadian or Mexican border, low senior presence) voting YES to 49.9 percent. A male Republican from this district obviously does not need any contribution to change his vote to a NO: Even without any contribution, he is voting against the bill.

Moreover, our calculations show that depending on the level of contributions, the effect of sharing a border with Canada or Mexico varies between 2 and 28 percentage points in the case of a Republican who is neither a free trader nor an internationalist, with a low senior presence. Our calculations also show that for a male Republican Representative who is neither a free trader nor an internationalist, the first $\$ 10,000$ contribution from PHARMA-CONTRIBUTE ( $\$ 0$ to $\$ 10,000$ ) changes the probability of a YES vote by 22 percentage points; the second \$10,000 PHARMACONTRIBUTE $(\$ 10,000-\$ 20,000)$ has a 19 percentage point impact; and the third $\$ 10,000(\$ 20,000-\$ 30,000)$ has a 12 percentage point impact. These numbers are 9, 16 and 21 percentage points, respectively, for a Democrat from the "same" district - i.e. no shared border and a high senior presence. These diminishing and increasing returns for Republicans and Democrats respectively could be explained by the very high probability of a YES vote of a Democrat (92 percent) and a relatively low probability of a YES vote of a Republican (63 percent) with no PHARMA-CONTRIBUTE.

Our regression analyses support the prediction of the political support approach: both campaign contributions and the constituency's interests are taken into account by Representatives. Our analysis also demonstrates that: (i) individual ideology matters, as does the gender of a Representative; and (ii) using IVs affects the magnitude and the significance of the estimated coefficients. The most interesting observation, however, is how big the PARTY effect was in measuring the probability of YES votes: The average difference between two Representatives whose only difference is their party affiliation was 36 percentage points. Depending on the level of contributions (between $\$ 0$ and $\$ 40,000$ ), this effect may take a value between 21 and 45 percentage points. For instance, two Representatives who are neither free traders nor internationalists, from a district with no Canadian or Mexican border and high senior presence, both receiving $\$ 16,000$ from PHARMA-CONTRIBUTE, the probability of a YES vote for a Republican Representative is 29 percent, and for a Democratic Representative it is 74 percent. 
Table 5 Rewards and Punishment Following the Vote

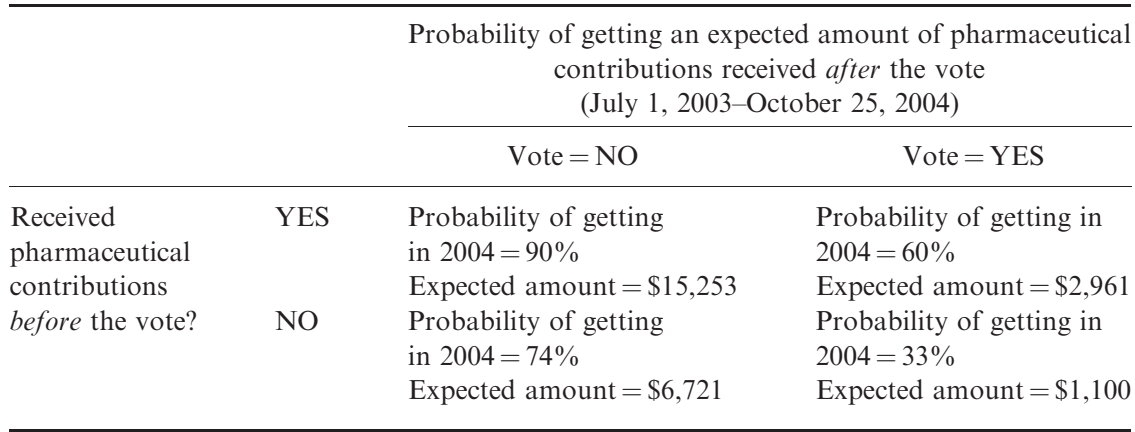

\subsection{Aftermath: Revisiting the Distribution of Contributions}

Finally, in this section, we briefly examine the aftermath of the bill: how did the pharmaceutical manufacturers react to not getting enough support from the legislators? Specifically, did they use their contributions to send signals to legislators? Table 5 presents a revealing picture. It shows that, perhaps after evaluating the performance of Representatives, i.e. their vote on H.R. 2427, pharmaceutical manufacturers implemented an incentive system that included both rewards and punishments: 90 percent of those who had received contributions in the 2002 cycle and voted NO received contributions in the next 16 months (July 1, 2003-October 25, 2004) with the average positive contribution being $\$ 15,253$. On the other hand, only 60 percent of those who had received contributions in the 2002 cycle but voted YES, received contributions in the next 16 months with the average positive contribution being only $\$ 2,961$ ! There is a mirror image of this picture for those who had not received any 2002 contributions: 74 percent of those who did not receive contributions in the 2002 cycle and voted NO received contributions in the next 16 months averaging $\$ 6,721$. On the other hand, only 33 percent of

Table 6 Ols Regression Estimate for After-Vote Pharmaceutical Contributions (Dependent variable: after-vote pharmaceutical contributions in $\$ 1,000$ )

\begin{tabular}{lccrc}
\hline Independent variable & $\begin{array}{c}\text { Coefficient } \\
(\beta)\end{array}$ & $\begin{array}{c}\text { Standard } \\
\text { error }\end{array}$ & $\begin{array}{l}t \text {-Statistic } \\
\text { Constant }\end{array}$ & $\begin{array}{c}\text { Significance } \\
\text { (two-tailed) }\end{array}$ \\
$\begin{array}{l}\text { VOTE on H.R. } 2427 \\
\quad(1 \text { if YES for re-importation) }\end{array}$ & -2.269 & 0.922 & 3.131 & 0.002 \\
$\begin{array}{l}\text { PHARMA-PAC (Campaign contributions } \\
\quad \text { in \$1,000) }\end{array}$ & 0.782 & 0.039 & 19.953 & 0.000 \\
\begin{tabular}{l} 
VOTE $\times$ PHARMA-CONTRIBUTE \\
\hline
\end{tabular} & -0.346 & 0.077 & -4.471 & 0.000 \\
\hline
\end{tabular}

Notes: Number of observations $=434$. Adjusted $R^{2}=0.573$. $F$-statistics $=195.048$. 


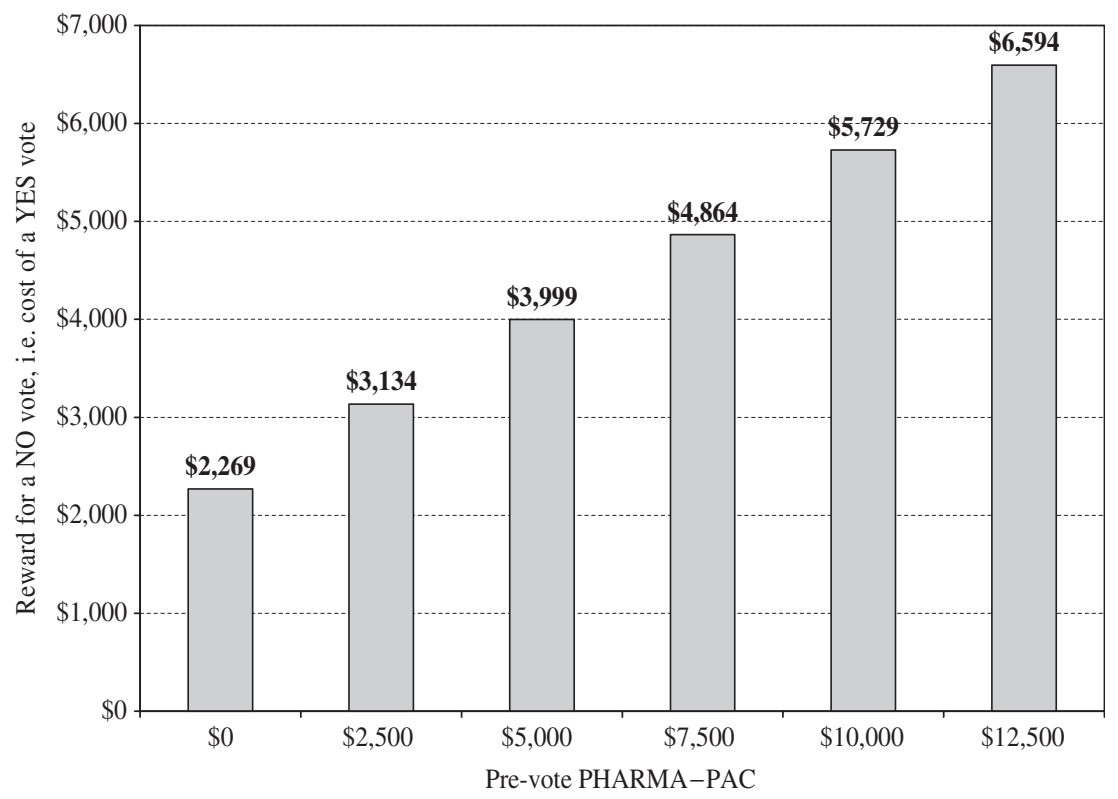

Figure 2. Reward for a NO vote, i.e. cost of a YES vote in terms of after-vote pharmaceutical contributions.

those who did not receive contributions in the 2002 cycle but voted YES received contributions in the next 16 months averaging $\$ 1,100$.

To further investigate this issue, we use regression analysis. In particular, we regress after-vote pharmaceutical contributions on VOTE - vote on H.R. 2427 ( 1 if yes, 0 otherwise) and PHARMA-CONTRIBUTE - pre-vote pharmaceutical contributions. Moreover, to model a possible interaction effect, we include VOTE $\times$ PHARMA-CONTRIBUTE. As is presented in Table 6, the estimated coefficients for VOTE and PHARMA-CONTRIBUTE and their interaction effect are statistically significant at the 1 percent level. Furthermore, there was a significant interaction effect: a YES vote alone turned into a $\$ 2,269$ cut in contributions. Yet, because of the interaction effect, as Figure 2 demonstrates, the same YES vote has a different nominal dollar effect on the after-vote pharmaceutical contributions depending on the amount of pre-vote pharmaceutical contributions. For instance, if a Representative had received $\$ 5,000$ in pre-vote contributions, the difference between a NO and a YES vote is $\$ 3,999$; if a Representative had received $\$ 10,000$ in pre-vote contributions, the difference is $\$ 5,729$; if a Representative had $\$ 15,000$ pre-vote contributions, the difference is $\$ 7,459$; and if a Representative had $\$ 20,000$ pre-vote contributions, the difference is $\$ 9,198 .{ }^{14}$

\footnotetext{
${ }^{14}$ Phillips and Tower (2004) found a qualitatively similar result for contributions by labor unions to Representatives in the periods surrounding the NAFTA vote.
} 


\section{CONCLUSION}

The results of this paper suggest that campaign contributions affected the vote by the 108th Congress on the Pharmaceutical Market Access Act. The other variables that we included in this study (i.e. whether a candidate represents a district within a state sharing a border with Canada or Mexico, the percentage of the population within a district over the age of 65 , and the size of employment in pharmaceutical manufacturing) also appear to have played a significant role in the vote.

The results fit well with the theory that campaign contributions affect the votes of legislators. Specifically, Representatives maximize electoral returns by balancing the acceptance of contributions in return for a vote on an issue which may cost the Representative support from informed voters with a contrary stance on the issue. The role of campaign contributions is shown by the negative relationship between contributions from pharmaceutical manufacturers, who oppose importation, and support for the bill. At the same time, there is a positive relationship between the prominence of two groups of informed voters within a Representative's district (namely senior citizens and people living close to Canada and Mexico) who largely support the bill, and the likelihood that the Representative will vote for the bill. Individual ideology and gender of a Representative also played a role in deciding how to vote on the bill. However, our analysis also reveals that the vote was by and large a partisan one: party affiliation was the most important factor in passing the bill.

\section{ACKNOWLEDGMENTS}

Gokcekus gratefully acknowledges 2004 URC Summer Research Stipend from Seton Hall University. We would like to thank the following for their help: Adam Godet, Amy Glass, Chris Magee, Marjorie McElroy, John McLaren, participants of SHU-Diplomacy School's Faculty Lunch Seminar, Second Annual Duke-Department of Economics Undergraduate Research Symposium, and the participants in the "Trade and Political Economy Sessions," at the 2004 Annual Meeting of the Southern Economic Association in New Orleans, and in particular the anonymous referee for constructive comments and suggestions. 


\section{REFERENCES}

Ansolabehere, S., J. M. de Figueiredo, and J. M. Snyder Jr., 2003, Why is there so little money in U.S. politics? Journal of Economic Perspectives 17(1), $105-130$.

Baldwin, R. and C. Magee, 2000, Is trade policy for sale? Congressional voting on recent trade bills. Public Choice 105, 79-101.

Biotechnology Industry Organization, 2004, The Gutknecht "drug importation" legislation poses immediate and incalculable risk to American patients. Fact Sheet, April 19, 2004. http://www.bio.org/reg/import/impfacts.asp.

Brink, S., 2003, Health on the border. U.S. News and World Report, 9 June.

Brown, K. M. and L. O. Taylor, 2000, Do as you say, say as you do: evidence on gender differences in actual and stated contributions to public goods. Journal of Economic Behavior \& Organization 43(1), 127-139.

Brown-Kruse, J. and D. Hummels, 1993, Gender effects in laboratory public goods contribution: do individuals put their money where their mouth is? Journal of Economic Behavior \& Organization 22(3), 255-267.

Burton, D., 2003, Low cost and safety of imported drugs, Congressman Dan Burton. http://www.house.gov/burton.

Chappell, H. W., 1982, Campaign contributions and Congressional voting: a simultaneous Probit-Tobit model. Review of Economics and Statistics 64, 77-83.

Comanor, W. S., 1986, The political economy of the pharmaceutical industry. Journal of Economic Literature 24, 1178-1217.

Fennemore, G. A. and J. P. Nelson, 2001, Western rangelands reform: an analysis of the 1996 Senate vote on federal grazing fees. Contemporary Economic Policy 19, 322-335.

Fisher, R., O. Gokcekus, and E. Tower, 2004, "Steeling" votes at low prices: Congressional voting patterns on the steel import quota bill of 1999, in: D. Nelson, ed., The Political Economy of Policy Reform (Elsevier, Amsterdam) 105-129.

Flaherty, M. P. and G. M. Gaul, 2003, Millions of Americans look outside U.S. for drugs: desire for low prices often outweighs obeying law. Washington Post, October 23, p. A01.

Frendreis, J. P. and R. W. Waterman, 1985, PAC contributions and legislative voting behavior: senate voting on trucking deregulation. Social Science Quarterly 66, 401-412.

Ganslandt, M. and K. E. Maskus, 2004, Parallel imports and the pricing of pharmaceutical products: evidence from the European Union. Journal of Health Economics 23(5), 1035-1057.

Gibbons, J., 2003, Gibbons wants to ensure patient safety. http://www.house.gov/ apps/list/press/nv02_gibbons/reimportdrugs0724.html.

Gokcekus, O., J. Phillips, and E. Tower, 2004, School choice: money, race and congressional voting behavior. Public Choice 119(1-2), 241-254.

Greene, W. H., 2003, Econometric Analysis, 5th edn. (Prentice Hall, Upper Saddle River, NJ).

Griswold, D., 2005, Free trade, free market: rating the 108th Congress. Cato Institute, Trade Policy Analysis Papers, No. 28.

Grossman, G. and E. Helpman, 1994, Protection for sale. American Economic Review 84(4), 833-850.

- and - 1996, Electoral competition and special interest politics. Review of Economic Studies 63, 265-286.

Gutknecht, G., 2003, Prescription drugs: H.R. 2427 - The Pharmaceutical Market Access Act. http://www.gil.house.gov/issues/pdrugs/pdrugs.htm. 
Hillman, A. L., 1982, Declining industries and political-support protectionist motives. American Economic Review 72, 1180-1187.

Kau, J. B. and P. H. Rubin, 1982, Congressmen, Constituents, and Contributors (Martinus Nijhoff, Boston, MA).

Krauss, M. I., 2003, Just say no to drug re-importation. Foxnews.com. http:// www.foxnews.com/story/0,2933,92767,00.html.

Langbein, L. I. and M. A. Lotwis, 1990, The political efficacy of lobbying and money: gun control in the U.S. House, 1986. Legislative Studies Quarterly 15, 413-440.

Longley, N., 2003, Modeling the legislator as an agent for the party: the effects of strict party discipline on legislator voting behavior. Contemporary Economic Policy 21, 490-499.

Moyers, S., 2003, Emerson backs bill to allow "reimport" of U.S. drugs, Southeast Missourian, May 20, 2003. http://www.house.gov/apps/list/press/mo08_emerson/ morenews/PhRMAVisit.html.

Pecorino, P., 2002, Should the US allow prescription drug reimports from Canada? Journal of Health Economics 21(4), 699-708.

Phillips, G. and E. Tower, 2004, Labor PAC campaign contributions and NAFTA legislators: rhetoric or retribution?, in: M. Plummer, ed., Empirical Methods in International Trade: Essays in Honor of Mordechai E. Kreinin (Edward Elgar, Cheltenham, UK) 169-186.

PhRMA, 2003a, Gutknecht-Emerson bill. What Should You Know 4(1), July 18, 2003. www.phrma.org/publications/policy/2003-07-18.796.pdf.

- 2003 b, House of Representatives action on H.R. 2427, the GutknechtEmerson bill. Quick Facts, July 25, 2003. http://www.phrma.org/publications/ quickfacts/25.07.2003.810.cfm.

Reinhardt, U., 2001, Perspectives on the pharmaceutical industry. Health Affairs 20(5), 136-149.

Saltzman, G. M., 1987, Congressional voting on labor issues: the role of PACs. Industrial and Labor Relations Review 40, 163-79.

Schroedel, J. R., 1986, Campaign contributions and legislative outcomes. Western Political Quarterly 34, 371-389.

U.S. House of Representatives, 2003, H.R. 2427 Pharmaceutical Market Access Act of 2003. (Bill in the House of Representatives, June 11, 2003.) http://thomas. loc.gov/cgi-bin/query/z?c108:H.R.2427. 